\title{
The Role of Organizational Learning Culture to Organizational Citizenship Behavior toward Knowledge Sharing Behavior
}

\author{
Yasir Syam Husain ${ }^{1}$, Buyung Sarita ${ }^{2}$, Dedy Takdir Syarifuddin ${ }^{3}$, Nurwati $^{4}$ \\ Doctoral Programme of Management Science, Halu Oleo University, Southeast Sulawesi, Indonesia
}

\begin{abstract}
This research was conducted to examine the role of organizational learning culture in moderating of OCB on knowledge sharing behavior. It was based on survey of 100 community facilitators. Structural equation modeling was used to test the hypothesis. The results showed that $O C B$ had a significant effect on knowledge sharing behavior, but this correlation was weak. It was also found that Organizational learning culture as a strong significant moderator of OCB toward knowledge sharing behavior. Sportmanship to receive a duty from the organization was the main reason for facilitators to share their knowledge. The existence of empowering people from these organizations had encouraged them to receive a duty as a form of responsibility from the organization so they provide to share their knowledge with their colleagues. Therefore, organizational learning culture had an important role to OCB on knowledge sharing behavior. There was another factor determining of knowledge sharing behavior that unreachable in this study so for future research may investigated such as job attitudes, subjective norms and perceived behavioral of control, etc. Moderating role of Organizational learning culture may develop to other variable on knowledge sharing behavior.
\end{abstract}

Keywords: Knowledge Sharing Behavior, Organizational Citizenship Behavior, Organizational Learning Culture, Facilitators, SEM

\section{Introduction}

Knowledge is a critical organizational resource that provides a sustainable competitive advantage in a dynamic and competitive economy (Davenport, et al., 1998). Knowledge is considered as a worth resource asset that makes competitive advantage to survive and remain in the market. The knowledge possessed by the firm is a strategic resource that can create a competitive advantage (Demsetz, 1988, Spender, 1996). Knowledge sharing is one of knowledge management which is as a process of knowledge exchange in the form of skills, experiences, and capabilities among coworkers or employees. Knowledge sharing refers to the preparation of information and knowledge to task of working with other people who can help a person to solve their problems, policies, or development of new ideas. (Pulakos et al., 2003). Moreover, knowledge was held by employees must be spread and shared with others as a strategy to maintain knowledge (Cabrera et al., 2006) and to minimize employee intent to leave the business (Hansen, 1999).

However, knowledge sharing has a few barriers. They are the lack of time, loss of awareness in knowledge management, and lost consciousness to knowledge (Leistner, 2010). The barriers occurred because knowledge was created and stored in the organization's members (Chow dan Chan, 2008), individual employees were less likely to share their knowledge (Ho et al., 2009). The sticky in transferring knowledge was a key issue in the firm, because the transfer of knowledge within the firm takes time, incurs costs, and uncertainty (Szulanski, 2003). Knowledge sharing behavior was generally not reasonable because people considered their knowledge as a valuable asset, and sharing of knowledge widely with others limited by the natural tendency to keep their information (Davenport and Prusak, 1998, cited Hsu et al., 2007). The reluctance of employees to share their knowledge with colleagues created problems for survival of the organization (Lin, 2007).

The results showed that the determinant of knowledge sharing behavior was OCB (Teh and Yong, 2011; Teh and Sun, 2012; Jofreh, 2014). Teh and Sun (2012) found that OCB had a significant effect on knowledge sharing behavior, but it couldn't mediate the correlation between job attitudes and knowledge sharing behavior (Teh and Sun, 2012). Al-zuhbi (2011) stated that OCB had a significant effect on knowledge sharing behavior which means that the more OCB employee the higher of knowledge sharing behavior. Civic virtue and courtesy was the most affect on knowledge sharing behavior (Yahaya et al., 2011). Moreover, Islam et.al. (2012) found that OCB had a significant effect on knowledge sharing behavior because of they had altruism, courtesy, sportsmanship, conscientiousness, and civic virtue.

A learning culture has an important role in improving the results of an organization (Ellinger et al, 2002; and Leonard, 1998), because the organization has a skill to produce, perform and disseminate knowledge on attitude changes (Garvin, 1993). Organization learning in the form of learning structure was a significant effect both on OCB individual and OCB organizations (Somech and DrachZahavy, 2004). The study showed that organizational learning culture directly affects to the knowledge sharing behavior so that the more of organization learning culture, the higher knowledge sharing behavior (Islam, 2012).

\section{Review of Literature}

\section{Knowledge Sharing Behavior}

Organizational knowledge is the knowledge - laid down in rules, procedures, strategies, technologies, conditions, paradigms, cultures and tenns of reference - that helps an organization to deal with its members. It is important that 


\section{International Journal of Science and Research (IJSR) \\ ISSN (Online): 2319-7064 \\ Index Copernicus Value (2013): 6.14 | Impact Factor (2014): 5.611}

organizational knowledge is independent of the individual actor who uses this knowledge. The knowledge must be able to survive substantial staff changes within the organization (Huysman and DeWit, 2002). Knowledge sharing is that activity which agents (individuals, communities or organizations) exchange their knowledge (information, skills or expertise). It is linked to the knowledge management process, which can be broadly characterized by four activities, the creation, storage and retrieval, transfer and application of knowledge (Ireson \& Burel, Knowledge Sharing in eCollaboration, 2010). Davenport and Prusak (1998) defined knowledge as "Knowledge is a fluid mix of framed experiences, values, contextual information, and expert insight that provide a framework for evaluating and incorporating new experiences and information". Knowledge sharing behavior is spread and share knowledge that has a value possessed other members in the organization (Ryu et al., 2003). Knowledge sharing is supported with different purposes, they are: to acquire knowledge, to reuse knowledge, and to develop new knowledge (Huysman and DeWit, 2002).

Knowledge sharing gains its importance from the role it plays over enhancing the overall performance of any organization, and the competitive advantages it adds to the corporate. Knowledge sharing is widely recognized to be a main component of successful knowledge management, and one of the central characteristics of healthy knowledge culture is that knowledge sharing is embedded in the way in which organization works (Seba, et. al., 2012). According to Lin (2007), knowledge sharing is fundamental to generate new ideas and developing new opportunities through the socialization and learning process of employees. Knowledge sharing plays an essential role in the organizational process because it helps an organization to transfer new ideas or solutions (Islam et al., 2010). Knowledge sharing is believed to be influenced by factors both at individual and organizational level (Naftanaila, 2010). At the individual level, one of the most important factors affecting knowledge transfer process is trust.

\section{Organizational Citizenship Behavior}

OCB is a discretion behavior and indirectly or explicitly appreciated in the context of official awards in organizational structure, but it contributed positively to organizational performance (Jarvenpaa and Staples, 2001; O'Donohue et al., 2007; Zboralski, 2009). Knowledge sharing is a form of OCB behavior that will be voluntary actions which help contribute to organizational competitive advantage. Organ (1988) stated that OCB is a discretionary individual behavior. Such behavior is indirectly or explicitly recognized by the formal reward system and the overall effectiveness of the functions that support organization. Organ (1988) suggested that there were five specific categories of behavior discretion that can help increase the efficiency of the organization. They are altruism, conscientiousness, sportsmanship, courtesy, and civic virtue.

OCB is a partial mediator (Islam et al 2012; Troena \& Noermijati, 2013; Sani, 2013). The study showed that OCB has a significant effect on knowledge sharing behavior (AlZu'bi, 2011; Ramasamy and Thamaraiselvan 2011; Teh and
Yong, 2011; Islam et al., 2012; Teh and Sun, 2012). It means that the more of OCB employee, the higher of employee knowledge sharing behavior. However, OCB is not be able to mediate correlation between job attitudes and knowledge sharing behavior (Teh and Sun, 2012), and has no significant effect on tacit of knowledge sharing behavior (Susanti and Wimbarti, 2014). Therefore, an increasing of OCB would not be given a significant effect to improve correlation between job attitudes and tacit of knowledge sharing behavior. Thus, it can be concluded that the improving of OCB would be affect the growth of knowledge sharing behavior. On the contrary, the lower of OCB would be produce knowledge sharing behavior in lower. Thus, it's proposed the hypotheses as follows:

H1: Organizational citizenship behavior has a significant effect on knowledge sharing behavior

\section{Organizational Learning Culture}

Behavioral Theory of the Firm (Cyert and March, 1963) stated that the firm as an adaptive system, where experiences were embedded in a number of standard operating procedures (routine) in which dispute resolution procedures based on the mechanism that has been set before. This theory was adopted by Huber (1991) and suggested that organizational learning is a process that occurs when components of the organization acquiring knowledge and recognize it as a potential benefit. Learning is one of organizational culture (Schein, 1993). The concept of organizational learning culture is a type of organizational culture that integrates with organizational learning. According to Bates and Khasawneh (2005), organizational learning culture is organizational phenomena that "support the acquisition of information, the distribution and sharing of learning, and that reinforce and support continuous learning and its application to organizational improvement" (p. 99). Thus, the goal of organizational learning culture is an exchange of valuable knowledge leading to innovation, improved performance, and sustained competitiveness (Lopez et al., 2005).

The study showed that organizational learning culture has a significant effect to knowledge sharing behavior (Holotezi, 2002; Issa and Haddad, 2008; Kouchaki et al., 2012; Bidokhti et al., 2011; Islam et al., 2011a, 2012; Idris et al., 2015; Shahhosseini and Nadi, 2015). Organizational learning culture was a moderator variable (Guo et al., 2014). Therefore, the improving of organizational learning culture would growth knowledge sharing behavior. But according to Goudarzi et al. (2009) showed that has no significant correlation between the organizational learning culture and knowledge creation. Thus, the increase of organizational learning culture would not provide a significant improvement to the knowledge creation. Organizational learning culture also has a significant effect on OCB (Somech and Drach-Zahavy, 2004; Islam, 2012). Furthermore, the more of organizational learning culture, the higher of OCB employees too. However, Pormand et al (2011) in Karimi and Akbari (2013) showed that has no significant correlation between organizational learning ability and OCB. Thus, it's proposed the hypotheses as follows:

\section{Volume 4 Issue 12, December 2015}




\section{International Journal of Science and Research (IJSR) \\ ISSN (Online): 2319-7064}

Index Copernicus Value (2013): 6.14 | Impact Factor (2014): 5.611

$\mathrm{H} 2$ : organizational learning culture moderates OCB toward the correlation between job attitudes and knowledge sharing behavior.

Thus, conceptual framework in this study can be seen in the following Figure.

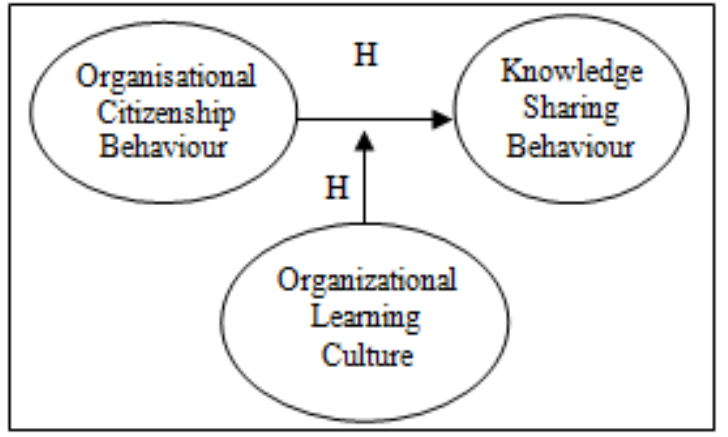

Figure 1: Conceptual Framework

Source: Developed by the author based on the data available.

\section{Research Methodology}

\section{Samples}

The samples for the present study consisted of 100 facilitators from selected 62 facilitators of P2KP, and 38 facilitators of SINTESA whom employee in South East Sulawesi of Indonesia. The data were collected during the period of January 2015 - November 2015 using a questionnaire and by personally visiting the organizations. The sample had 67 men (67.00 per cent) and 33 women (33.00 per cent). The sample had their age varying between 20 years and 60 years which consists of a respondent aged 20 years old, 27 respondents among 21-30 years old, 52 respondents among 31-40 years old, and 20 respondents was over 40 years old. Also, the sample had 90 graduates $(90.00$ per cent), 6 undergraduates ( 6.00 per cent), and 4 senior high school (4.00 per cent) as far as their education levels were concerned. Of the samples, 57.00 per cent were field facilitators', 20.00 per cent were administrative personnel, 11.00 per cent were middle managements', 10.00 per cent were supervisors, and 2.00 per cent were managers. The work experience of the samples was also mixed: below 5 years (61.00 per cent), in between 6 and 10 years (31.00 per cent) and more than 10 years $(8.00$ per cent $)$.

\footnotetext{
Measures

Standardized instruments were used for collecting the data. Organizational citizenship behavior (OCB) is measured based on five main indicators developed Organ (1988). Altruism was the first indicator in this scale and measured using three items. Civic virtue was the second indicator in this scale and measured using four items. Contentiousness was the third indicator in this scale and measured using four items. Courtesy was the fourth indicator in this scale and measured using three items. Sportsmanship was the fifth indicator in this scale and measured using three items. Organizational learning culture (OLC) is measured based on seven main indicators developed by Watkins and Marsick (2003). Continuous learning was the first indicator in this
}

scale and measured using three items. Interaction and dialogue was the second indicator in this scale and measured using three items. Collaborative and team were the third indicator in this scale and measured using three items. Creating a system was the fourth indicator in this scale and measured using three items. Empowering people was the fifth indicator in this scale and measured using three items. Connecting organizations was the sixth indicator in this scale and measured using three items. Leadership strategy was the seventh indicator in this scale and measured using three items. Knowledge sharing behavior (KSB) is measured based on two main indicators developed by De Vries et al. (2006); and Tohidinia and Mosakhani (2010). Knowledge donation was the first indicator in this scale and measured using four items. Knowledge collection was the second indicator in this scale and measured using four items. The employee responded on a 5-point Likert scale (1 means strongly disagree, 5 means strongly agree).

\section{Data Analysis and Result}

Statistic descriptive was used to describe the variable in generally. The descriptive score of altruism was $(\mathrm{M}=3.88$, $\mathrm{SD}=0.74)$, civic virtue was $(\mathrm{M}=3.70, \quad \mathrm{SD}=0.82)$, contentiousness was $(\mathrm{M}=3.84, \mathrm{SD}=0.84)$, courtesy was $(\mathrm{M}=4.01, \quad \mathrm{SD}=0.75)$, and sportsmanship was $(\mathrm{M}=3.94$, $\mathrm{SD}=0.85)$. Moreover, the mean and standard deviation of continuous learning was $(\mathrm{M}=4.08, \mathrm{SD}=0.70)$, interaction and dialogue was $(\mathrm{M}=3.85, \mathrm{SD}=0.77)$, collaborative and team was $(\mathrm{M}=3.82, \mathrm{SD}=0.73)$, creating a system was $(\mathrm{M}=4.07$, $\mathrm{SD}=0.73)$, empowering people was $(\mathrm{M}=3.83, \mathrm{SD}=0.72)$, connecting to organizations was $(\mathrm{M}=4.12, \mathrm{SD}=0.71)$, and leadership strategy was $(\mathrm{M}=3.99, \mathrm{SD}=0.74)$.Thus, the descriptive score of knowledge donation was $(\mathrm{M}=3.87$, $\mathrm{SD}=0.77)$ and knowledge collection was $(\mathrm{M}=3.79$, $\mathrm{SD}=0.73)$.

Confirmatory factor analysis was processed using AMOS 22 to test the strength of indicator variable should confirm the lamda value in range of $\geq 0.40$ (Ferdinand, 2005). Organizational citizenship behavior had been also confirmed by five indicators. They were sportsmanship which had $\lambda$ of 0.68 , courtesy which had $\lambda$ of 0.65 , civic virtue which had $\lambda$ of 0.59 , contentiousness which had $\lambda$ of 0.58 , and altruism which had $\lambda$ of 0.56 . Furthermore, the moderation variable of OLC as interaction between OCB and OLC had 35 of interactions from each indicator both OCB and OLC. Its results showed that all of items were more than 0.40 so they could confirm OLC as a moderation variable of OCB. Interaction between empowerment of people and sportsmanship was the most of confirmation factor which $\operatorname{had} \lambda$ of 0.86 .

Finally, to test the hypotheses was performed through structural equation model (SEM) processed by AMOS 22. For the moderation variable, it was use Ping and Jöreskog methods, as stated by Rohman, Solimun, and Soehono (2013), to interact OLC with OCB. The test results of Structural Equation Model (SEM) can be seen in following Figure. 
International Journal of Science and Research (IJSR)

ISSN (Online): 2319-7064

Index Copernicus Value (2013): 6.14 | Impact Factor (2014): 5.611

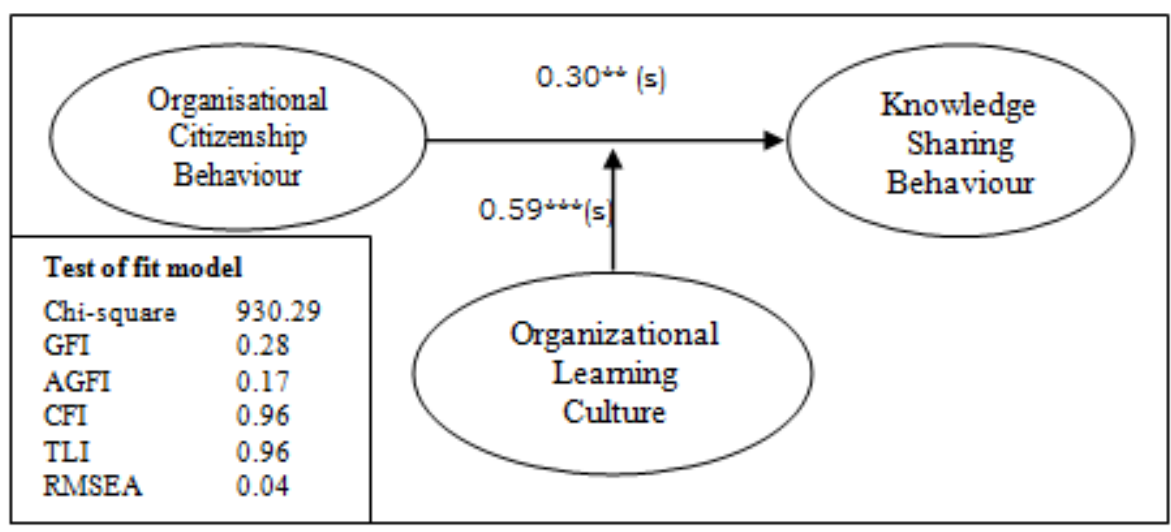

Figure 2: Structural Equation Model (SEM)

Source: developed by author based on the data available

The results as shown on Figure 2, that the effect of organizational citizenship behavior on knowledge sharing behavior was about 0.30 (s) in $\alpha<0.05$, and the effect of organizational learning culture in moderating of OCB on knowledge sharing behavior was about 0.59 (s) in $\alpha<0.01$. Widarjono (2010) stated that the model is to be feasible if at least one method of testing the feasibility of the model is fulfilled because in practice it is very difficult to meet the fifth test feasibility. However, when testing the feasibility of the model can meet more than one eligibility criterion model, SEM will be better than only one who fulfilled. The model as shown in Figure 2 showed that the result of test fit indices to CFI was about 0.96 , TLI was about 0.96 , and RMSEA was about 0.04. It was stated by Hair et al. (1995) that the value of fit indices to CFI and TLI of $\geq 0.95$, and RMSEA of $\leq 0.08$ were within the expected range of fit indices that could be accepted. Therefore, it could be accepted even thought the value of fit indices for Chisquare, GFI, and AGFI were not within the expected value. Finally, it could be concluded the hypotheses that previous proposed as following:

$$
\begin{aligned}
& \mathrm{H} 1: \mathrm{OCB} \rightarrow \mathrm{KSB} \quad=\text { accepted } \\
& \mathrm{H} 2: \mathrm{OCB} \times \mathrm{OLC} \rightarrow \mathrm{KSB}=\text { accepted }
\end{aligned}
$$

\section{Discussion}

The study found that the OCB had a significant positive effect on knowledge sharing behavior. Hypothesis (H1) stated that OCB has a significant effect could be accepted. Therefore, good facilitators' OCB will improve knowledge sharing behavior facilitators in assisting the community. It means that the more $\mathrm{OCB}$, the higher of knowledge sharing behavior. Delivering of the basic things associated with the job is the biggest factor that makes them have courtesy to share knowledge to their colleagues. This finding is consistent with Teh and Sun (2012) research who stated that OCB has a significant effect on knowledge sharing behavior. This finding was also supported by various studies such as Al-Zu'bi (2011); Ramasamy and Thamaraiselvan (2011); Teh and Yong (2011); Islam et al. (2012); Hsu and Lin (2008); and Susanti and Wimbarti (2012).

The study showed that organizational learning culture had a significant effect in moderating of OCB on knowledge sharing behavior. Hypothesis (H2) stated that the organizational learning culture moderates OCB toward the correlation with knowledge sharing behavior could be accepted. Thus, organizational learning culture is a strongly significant moderator of OCB to growth of knowledge sharing behavior. Therefore, organizational learning culture has an important role to strengthen of organizational citizenship behavior toward correlation with knowledge sharing behavior. The more organizational learning culture, the higher strengthen of OCB to improve of knowledge sharing behavior. Empowering people was the main reason that strengthens of sportsmanship to knowledge sharing behavior. Inviting people to contribute to the organizations's vision strengthened the adaption of employement to the work so they more provide to share their knowledge with their colleagues. This study is consistent with suggestions Teh and Sun (2012) suggested that is needed for other variable to moderate $\mathrm{OCB}$ in strengthening to correlation on knowledge sharing behavior.

Theoretically, organizational learning culture was one of form of Behavioral Theory of the Firm applied by non-profit organizations. According to the Behavioral Theory of the Firm as proposed by March (1962) in Augier (2004) that the firm as an adaptive system between political coalition, cooperation between individuals and another groups within the firm who has the distinction of each destination so allowing conflicts of interest. Empirically, it was supported by findings research of Drach Somech-Zahavy, 2004; Issa and Haddad, 2008; Islam et al., 2011; 2012; Idris et al., 2015; Shahhosseini and Nadi, (2015).

\section{Conclusion}

Based on the results, it can be concluded that: firstly, organizational citizenship behavior has a positive significant effect on knowledge sharing behavior. Finally, it was found that organizational learning culture has given a positive significant effect in moderating organizational citizenship behavior toward correlation between OCB and knowledge sharing behavior. Thus, the higher of organizational learning culture, the more strengthen of OCB to improve of knowledge sharing behavior. Furthermore, it was define that organizational learning culture has an important role to strengthen of organizational citizenship behavior on knowledge sharing behavior. 


\section{International Journal of Science and Research (IJSR) \\ ISSN (Online): 2319-7064}

Index Copernicus Value (2013): 6.14 | Impact Factor (2014): 5.611

\section{Limitations and Future Research}

The determination factor of knowledge sharing behavior has still remained another factor that unreachable in this research. Another variable could be also examined as an impact factor of knowledge sharing behavior in future research such as job attitudes, subjective norms and perceived behavioral of control, etc. This study only limited to investigate the moderation role of organizational learning culture to OCB which there is an another possibility to impact in another variable that unreachable in this study so that in future research may develop a moderation role to other on knowledge sharing behavior. The samples of this research were facilitators of non-profit organizations so that in future research may come from another profession. Future research may design a longitudinal study to test the model of knowledge sharing behavior.

\section{References}

[1] Al-Zu'bi, H.A., 2011. Organizational Citizenship Behavior And Impacts On Knowledge Sharing: An Empirical Study. International Business Research. Vol. 4, No. 3.

[2] Bates, R., \& Khasawneh, S., 2005. Organizational learning culture, learning transferclimate and perceived innovation in Jordanian organizations. International Journal of Training and Development, 9(2), 96-109.

[3] Bidokhti A, Hosseini S.H., Ehsani Z., 2011. Relationship Between Organizational Culture And Knowledge Management In Educationc Organization Of Semnan. No. 59:191-216

[4] Cabrera, A., Collins, W., Salgado, J., 2006. Determinants of Individual Engagement In Knowledge Sharing. International Journal of Human Resource Management; 245: 17-2

[5] Chow, W.S., \& Chan, L.S., 2008. Social Network, Social Trust And Shared Goals In Organizational Knowledge Sharing. Information \& Management, Vol. 45 No. 7, pp. 458-65.

[6] Cyert, R. M., \& March, J. G., 1963. A behavioral theory of the firm . Englewood Cliffs, NJ: PrenticeHall.

[7] Davenport, T.H., \& Prusak, L., 1998. Working Knowledge: How Organizations Manage What They Know. Harvard Business School Press, Boston, MA.

[8] Demsetz, Harold., 1988. The Theory Of The Firm Revisited , Journal of Law, Economics, and Organization, 141-161.

[9] Ellinger A.D., Ellinger A.E., Yang. B., Howton SW., 2002. The Relationship Between The Learning Organization Concept And Firms' Financial Performance: An Empirical Assessment. Human Resource Development

[10] Ferdinand, 2005. Structural Equation Modelling Dalam Penelitian Manajemen. Semarang, BP UNDIP.

[11] Goudarzi, M., Abutorabi, M., Dastigardi, M., \& Dastigardi, K., 2009. Relationship Between Organizational Culture And Knwledge Management In Directors of Physical Education Organization; J. Sport Manage. (motion). 6(2):201-214.

[12] Guo, Y., Wang,C., \& Feng, Y., 2014. The Moderating Effect of Organizational Learning Culture on
Individual Motivation and ERP System Assimilation at Individual Level. Journal of Software, Vol 9, No 2 (2014), 365-373, doi:10.4304/jsw.9.2.365-373

[13] Hair, J. F. Jr., Anderson, R. E, Tatham, R. L. \& Black, W. C.,1995. Multivariate data analysis. New Jersey, Prentice Hall International Editions.

[14] Hansen, M.T., Nohria, N., \& Tierney, T., 1999. What's Your Strategy For Managing Knowledge?. Harvard Business Review, pp. 106-16.

[15] Ho, C.T.B., Hsu, S.F., \& Oh, K.B., 2009. Knowledge Sharing: Game And Reasoned Action Perspectives, Industrial Management \& Data Systems, Vol. 109 No. 9, pp. 1211-30.

[16] Holotezi, A.,2002. The Relationship Between Knowledge Management And Organizational Culture. Applied Information Management And The Gradute School Of The : J. university of orergon, 3(2):15-22

[17] Hsu, M.H., Ju, T.L., Yen, C.H., \& Chang, C.M., 2007. Knowledge Sharing Behavior In Virtual Communities: The Relationship Between Trust, Self-Efficacy, and Outcome Expectations. International Journal of Human-Computer Studies, Vol. 65, pp. 153-69.

[18] Huber, G. P., 1991. Organizational Learning: The Contributing Processes and the Literatures. Organization Science, 2, 88-115.

[19] Huysman and Dewit, 2002. Knowledge Sharing In Practice. Springer Science. Business Media, B.V.

[20] Idris, K.M., Nita, A.K., \& Godwin, A.U., 2015. Impact Of Organizational Culture On Knowledge Management Process In Construction. Asian Social Science; Vol. 11, No. 9. ISSN 1911-2017 E-Issn 19112025

[21] Ireson , N., \& Burel, G., 2010. Knowledge Sharing in eCollaboration.

[22] Islam Z, Ahmad ZA, Mahtab H., 2010. The Mediating Effects of Socialization On Organizational Contexts And Knowledge Sharing. J. Knowl. Global. 3(1): 3148.

[23] Islam, M.Z., Ahmed,S.M., Hasan, I., \& Ahmed, S.U., 2011. Organizational Culture And Knowledge Sharing: Empirical Evidence From Service Organizations. African Journal of Business Management Vol. 5(14), pp. 5900-5909. Available online at http://www.academicjournals.org DOI: 10.5897/AJBM11.073 ISSN 1993-8233

[24] Islam, T., Anwar,F., Rehman Khan, S.U, Rasli, A., Norulkamar, U., Ahmed, I., 2012. Investigating The Mediating Role of Organizational Citizenship Behavior Between Organizational Learning Culture And Knowledge Sharing. World Applied Sciences Journal 19 (6): 795-799, 2012 ISSN 1818-4952, DOI: 10.5829/idosi.wasj.

[25] Issa, Raja R.A., \& Haddad, Josef., 2008. Perceptions of the Impacts of Organizational Culture and Information Technology on Knowledge Sharing In Construction. Construction Innovation. Vol. 8 No. 3, 2008 pp. 182-201. Emerald Group Publishing Limited.1471-4175.DOI 10.1108/14714170810888958

[26] Jarvenpaa, S.L., \& Staples, D.S., 2001. Exploring Perceptions of Organizational Ownership of Information And Expertise. Journal of Management Information Systems, Vol. 18 No. 1, pp. 151-83.

\section{Volume 4 Issue 12, December 2015}




\section{International Journal of Science and Research (IJSR) \\ ISSN (Online): 2319-7064}

Index Copernicus Value (2013): 6.14 | Impact Factor (2014): 5.611

[27] Jofreh, M., Aghaei,T., Mamqani, N.B., 2014 Investigating The Impact Of Job Attitudes On Organizational Citizenship Behavior And Knowledge Sharing. Journal of Educational and Management Studies. J. Educ. Manage. Stud.,4 (2): 332-337, 2014. ISSN: 2322-4770

[28] Karimi,F., \& Akbari, M., 2013. Predicting Organizational Citizenship Behavior on the Basis of Organizational Learning Capability. Middle-East Journal of Scientific Research 18 (9): 1371-1379, DOI: 10.5829/idosi.mejsr. 2013.18.9.12381

[29] Kouchaki M., Ghayoomi A., \& Moradi N., 2012. Studying The Relationship Between Organizational Culture (Queen's Model) And Feasibility of Establishment of A Knowledge Management System In Iranian Gas Transmission Company; $J$. Occupational Organizational Consulting. 13(12):101121.

[30] Leistner, F., 2010. Mastering Organizational Knowledge Flow: How To Make Knowledge Work. John Wiley \& Sons, Inc., Hoboken, New Jersey

[31] Leonard, D., 1998. Wellsprings of knowledge: Building and sustaining the sources of innovation. Boston: Harvard Business School Press.

[32] Lin, C.P., 2007. To Share Or Not To Share: Modeling Knowledge Sharing Using Exchange Ideology as A Moderator. Personnel Review, Vol. 36 No. 3, pp. 45775.

[33] Lopez, S. P., Peon, J. M. M., \& Ordas, C. J. V., 2005. Organizational learning as a determining factor in business performance. The Learning Organization, 12(3), 227-245.

[34] O’Donohue, W., Sheehan, C., Hecker, R. and Holland, P., 2007. The Psychological Contract Of Knowledge Workers. Journal of Knowledge Management, Vol. 11 No. 2, pp. 73-82.

[35] Organ., D. W., 1988. Organizational Citizenship Behavior: The Good Soldier Syndrome. Lexington, MA: Lexington.

[36] Pulakos, E.D., Dorsey, D.W., \& Borman, W.C., 2003. Hiring For Knowledge-Based Competition. Managing Knowledge for Sustained Competitive Advantage Designing Strategies for Effective Human Resource Management. John Wiley \& Sons, Inc.

[37] Ramasamy, M., \& Thamaraiselvan, N., 2011. Knowledge Sharing and Organizational Citizenship Behavior. Knowledge and Process Management, Volume 18 Number 4 pp 278-284 (2011) Published online in Wiley Online Library (wileyonlinelibrary.com) DOI: 10.1002/kpm.385.

[38] Rohman, M.Z., Solimun, Soehono, L.A., 2013. Identifikasi variabel moderasi pada pemodelan struktural dengan pendekatan interaksi Indikator tunggal Jurusan Matematika, F.MIPA, Universitas Brawijaya

[39] Ryu, S., Ho, S.H. \& Han, I., 2003. Knowledge Sharing Behavior of Physicians In Hospitals. Expert Systems with Applications, Vol. 25 No. 1, pp. 113-22.

[40] Sani, A., 2013. Role of Procedural Justice, Organizational Commitment and Job Satisfaction on job Performance: The Mediating Effects of Organizational Citizenship Behavior. International
Journal of Business and Management; Vol. 8, No. 15; ISSN 1833-3850 E-ISSN 1833-8119.

[41] Schein, E.H., 1993. Organizational Culture and Leadership. San Francisco, CA: Jossey Bass.

[42] Seba, I., Rowley, J., \& Lambert, S., 2012. Factors Affecting Attitudes and Intentions Towards Knowledge Sharing in Dubai Police Force. International Journal of Information Management, 1120.

[43] Shahhosseini, S., \& Nadi, M.A., 2015. Analyzing the Relationship of Organizational Trust and Organizational Culture with Knowledge Sharing Behavior in Teachers of Second Intermediate Period. Academic Journal. Vol. 10(6), pp. 722-727, 23 March, 2015 DOI: 10.5897/ERR2015.2125. Article Number: 125FC7B51405. ISSN 1990-3839

[44] Somech, Anit, \& Drach-Zahavy, Anat., 2004. Exploring Organizational Citizenship Behaviour From an Organizational Perpective: The Relationship Between Organizational Learning and Organizational Citizenship Behavior. Journal of Occupational and Organizational Psychology; 77, ProQuest pg. 281

[45] Spender, J.C., 1996. Making Knowledge The Basic Of Dynamic Theory of The Firm. Strategic Management Journal, Vol. 17. John Wiley \& Sons.

[46] Susanti, R., \& Wimbarti, S., 2012. Pengaruh Organizational Citizenship Behavior (OCB) dan Persepsi Atas Dukungan Organisasi terhadap Knowledge Sharing dan Jenis Kelamin sebagai Moderator pada Karyawan PT. Telekomunikasi Indonesia Tbk, Kandatel Yogyakarta. Jurnal Psikologi, Volume 8 Nomor 1, Juni 2012

[47] Szulanski, G. (2003). Sticky Knowledge. Barriers to Knowing in the Firm. Sage Publication.

[48] Teh, P.L. \& Sun, H., 2012. Knowledge Sharing, Job Attitudes and Organisational Citizenship Behaviour. Industrial Management \& Data Systems, Vol. 112 No. 1, pp. 64-82

[49] Teh, P.L., \& Yong, C.C., 2011. Knowledge Sharing In IS Personnel: Organizational Behavior's Perspective. Journal of Computer Information Systems.

[50] Tohidinia, Z., \& Mosakhani, M., 2010. Knowledge Sharing Behavior and Its Predictors. Industrial Management \& Data Systems, Vol. 110 No. 4, pp. 611-31.

[51] Marsick, V.J., and Watkins, K.E., 2003. Demonstrating the Value of an Organization's Learning Culture: The Dimensions of the Learning Organization Questionnaire. Advances in Developing Human Resources Vol. 5, No. 2, 132-151 DOI: $10.1177 / 1523422303251341$

[52] Widarjono, A., 2010. Analisis Statistika Multivariat Terapan. UPP STIM YKPN.

[53] Yahaya, A., Boon, Y., Ramli, J., Baharudin, N.A., Yahaya, N., Ismail, J., and Shariff, Z., 2011. The Implications Of Organizational Citizenship Behavior (OCB) Towards The Dimensions Of Learning Organization (LO) In Organizations In Southern Malaysia. African Journal of Business Management, Vol. 5(14), pp. 5724-5737, Available online at http://www.academicjournals.org

DOI: 10.5897/AJBM11.001 ISSN 1993-8233. 


\section{International Journal of Science and Research (IJSR) \\ ISSN (Online): 2319-7064}

Index Copernicus Value (2013): 6.14 | Impact Factor (2014): 5.611

[54] Zboralski, K., 2009. Antecedents of Knowledge Sharing In Communities of Practice. Journal of Knowledge Management, Vol. 13 No. 3, pp. 90-101.

Volume 4 Issue 12, December 2015 www.ijsr.net 